Aksiologiya: Jurnal Pengabdian Kepada Masyarakat

Vol.5, No. 2, Mei 2021 Hal 163 - 171

ISSN 2528-4967 (print) dan ISSN 2548-219X (online)

\title{
Optimalisasi Keterampilan Menulis Pada Guru
}

\author{
Khodijah Hayati ${ }^{1}$, Fitri Amilia ${ }^{2}$ \\ ${ }^{1}$ Universitas terbuka \\ ${ }^{2}$ Universitas Muhammadiyah Jember \\ Email : hayati@ecampus.ac.id ${ }^{1}$, fitriamilia@unmuhjember.ac.id²
}

\begin{abstract}
ABSTRAK
Kemampuan dan keterampilan membaca menulis mutlak menjadi kompetensi yang harus dimiliki setiap guru. Kemampuan membaca dapat diukur dalam kegiatan berbicara dan menulis. Kemampuan menulis mencerminkan keterampilan berbahasa secara keseluruhan. Berdasarkan observasi, dibutuhkan kegiatan pelatihan dan pendampingan untuk meningkatkan keterampilan menulis pada guru di desa Pakusari meliputi keterampilan menulis teks buku ajar dan artikel ilmiah. Kegiatan pelatihan dan pendampingan ini merupakan rangkaian kegiatan pengabdian Masyarakat (Abdimas) bertema literasi di Desa Pakusari mulai tahun 2017 hingga 2019. Hasil pelaksanaan Abdimas pada guru Sekolah Dasar dan Guru Pendidikan Anak Usia Dini di Desa Pakusari menunjukkan bahwa keterampilan menulis guru sudah baik. Luaran dalam kegiatan ini berupa buku cerita, buku bergambar, dan lembar kerja siswa menjadi bukti konkret keterampilan mereka. Namun, kurangnya motivasi, sarana, dan pembiasaan menulis menjadi hambatan dalam kegiatan menulis. Untuk itu, diperlukan kerja sama semua pihak agar kompetensi guru bisa terus menerus ditingkatkan. Kompetensi guru yang baik akan menjadi dasar dalam pengembangan pendidikan dan pembelajaran.
\end{abstract}

Kata Kunci: menulis; kompetensi guru.

\section{Optimization of Teacher's Writing Skills}

\begin{abstract}
The reading and writing skills have absolutely become competency that must be possessed by teachers. Reading ability can be measured through speaking and writing activities. Writing skills reflect overall language skills. Based on observations, training and mentoring activities are needed to improve writing skills of textbook and scientific articles for teachers in Pakusari. This training and mentoring activity is the series of Community Service (Abdimas) on literacy-based theme activities in Pakusari from 2017 to 2019. This activity was implemented for teachers of Elementary school and Early Childhood Education in Pakusari. The results of the implementation show that the teacher's writing competency is good. The teachers have been able to create story books, picture books, and student worksheets as the concrete evidence of their ability in writing skills. However, lack of motivation, tools, and habit of writing, have become obstacles in writing activities. For this reason, collaboration between all parties is needed so that teacher's competencies can continuously be improved. Competent teacher is the basis in the development of education and learning.
\end{abstract}

Key Words: teacher competencies; writing.

\section{PENDAHULUAN}

Kajian menulis tidak pernah berhenti dibahas. Berdasarkan penelusuran pembahasan menulis dalamkegiatan belajarselalumendapat perhatian. Banyaknya jumlah artikel 
dengan tema menulis menjadi bukti pentingnya keterampilan ini. Tidak hanya itu, menulis menjadi salah indikator pencapaian kompetensi literasi. Hal ini dapat dibuktikan dengan adanya program Gerakan Literasi Sekolah (GLS) yang digalakkan oleh Kementerian Pendidikan dan Kebudayaan. Kegiatan baca tulis merupakan salah satu kompetensi literasi dasar disamping literasi numerasi, sains, digital, finansial, budaya dan kewargaan (2015). Literasi dasar ini harus mulai dikembangkan guru Pendidikan Dasar untuk menumbuhkembangkan kecakapan di abad 21 ini.

Sebelum menanamkan kecakapan literasi pada murid, guru hendaknya menjadi model. Guru sebagai model mampu menunjukkan kecapakannya dalam membaca dan menulis. Amilia (2018) menyebutan bahwa keteladan guru akan menjadi salah satu daya tarik dalam pengembangan literasi di sekolah. Ia mencontohkan bahwa kebiasaan guru dalam membaca dan menulis akan menjadi contoh untuk muridmuridnya. Keteladanan ini akan menjadi dasar, pondasi, dan bekal dalam pencapaian kecakapan literasi dasar.

Keterampilan menulis sangat penting untuk menunjukkan profesiolitas guru. Keterampilan menulis akan mencerminkan empat kompetensi guru, meliputi kompetensi pedagogi, profesional, sikap, dan kepribadian. Hal ini sesuai dengan konsep pengembangan kompetensi guru yang diungkap oleh
Musfah (2012). Dia menyatakan guru profesional senantiasa merencanakan segala aktivitasnya untuk terus meningkatkan pengetahuan, sikap, perbuatan, dan keterampilan. Melalui kegiatan menulis, akan terekam jejak peningkatan kompetensi tersebut.

Banyak yang melaporkan hasil kegiatan untuk meningkatkan kemampuan menulis untuk guru. Fitria, Kristiawan, \& Rahmat (2019) menuliskan pentingnya keterampilan menulis penelitian tindakan kelas bagi guru. Sebelumnya, Sodiq, Suryadi, \& Ahmad (2014) melaporkan bahwa peningkatan keterampilan menulis dapat dilakukan dengan pelatihan. Hal ini menunjukkan bahwa pengetahuan merupakan pijakan dalam menulis. Tulisan atau karya guru merupakan bukti dari pengetahuan dan kompetensi yang dimilikinya.

Berdasarkan observasi dan wawancara pada guru di Pendidikan Anak Usia Dini dan Sekolah Dasar ditemukan fenomena kurang maksimalnya pembiasaan menulis di kalangan guru. Guru sudah mengajar dengan cara terbaik sesuai analisis kebutuhan peserta didik. Namun, guru belum memiliki komitmen untuk selalu menulis, sehingga siswa pun hanya menulis kata dan kalimat sesuai instruksi tanpa adanya upaya menulis gagasan atau ide kreatif.

Fenomena ini disebabkan banyak faktor. Pertama, guru belum menjadi teladan dalam kegiatan menulis.Disekolahdasartelahdijumpai adanya majalah dinding (mading). Guru belum memaksimalkan mading tersebut sebagai transfer pengetahuan 
dan gagasan. Mading hanya menjadi media siswa menulis tanpa adanya komunikasi tulisan antara guru dan siswa dalam mading yang sama. Fenomena ini menunjukkan bahwa teladan menulis belum dilakukan guru secara maksimal. Idealnya, guru menjadi teladan dalam kegiatan menulis; siswa akan terinspirasi untuk menulis tanpa paksaan.

Kondisi berbeda dengan guru di sekolah Pendidikan Anak Usia Dini yang belum memiliki mading untuk publikasi tulisan siswa. Namun, di PAUD ini aneka karya siswa bisa dipajang dan dipamerkan dikelasuntuk menarik minat dan kreativitasnya. Ketiadaan sarana ini menjadikan guru PAUD tidak memiliki media dalam menulis. Belum ada ide untuk menghadirkan atau memilih sarana untuk bisa menulis dengan efektif. Hal ini menjadi faktor kedua atas fenomena belum adanya pembiasaan menulis di kalangan guru.

Untuk mencapai pembiasaan atau habituasi menulis, guru perlu membiasakan diri menulis. Amilia (2018) menyatakan siswa perlu dibiasakan dalam menulis. Pembiasaan menulis di kalangan siswa akan membangun keterampilan menulis. Tugas guru adalah melatih dan membiasakan kegiatan menulis dalam setiap kegiatan pembelajaran. Tema tulisan untuk siswa sekolah dasar bisa beraneka ragam, seperti puisi, cerita pengalaman pribadi, dan aneka tulisan santai lainnya.

Atas dasar ini, kegiatan pengabdian ini dirancang untuk menyiapkan guru yang memiliki panggilan jiwa dalam pengembangan literasi di sekolah. Kegiatan ini juga dilakukan atas dasar kerja sama dengan mitra yaitu Pemerintah Desa Pakusari dalam tiga tahun pelaksanaan kegiatan Pengabdian Masyarakat (Abdimas). Dengan adanya kegiatan ini, ada harapan berupa peningkatan kompetensi literasi khususnya bagi pegiat pendidikan. Kegiatan ini dititikberatkan pada pelatihan menulis buku ajar untuk siswa dan artikel ilmiah. Pegiat pendidikan yang menjadi peserta dalam kegiatan ini adalah guru Sekolah Dasar dan Guru PAUD yang ada di desa Pakusari. Jumlah peserta dalam kegiatan ini adalah 25 guru.

\section{METODE PELAKSANAAN}

Secara umum kegiatan Abdimas ini dilaksanakan dengan metode lokakarya. Istilah lokakarya digunakan untuk merujuk pada kegiatan ilmiah dengan target luaran produk yang lebih terukur. Lokakarya terangkai dalam kegiatan pemberian materi, pendalaman materi, dan pelatihan penguatan materi. Richards \& Farrell (2005) menjelaskan bahwa lokakarya merupakan kegiatan pembelajaran yang relatif pendek untuk bertukar informasi, melatih keterampilan, dan mendapatkan umpan balik. Istilah lain dari lokakarya adalah workshop.

Berdasarkan hasil penelitian, rangkaian kegiatan pelatihan dapat mengubah dan atau meningkatkan kompetensi guru. Sa'bani (2017) melaporkan bahwa kegiatan pelatihan dapat meningkatkan kompetensi guru dalam menyiapkan rencana kegiatan 
pembelajaran. Dengan demikian, metode ini dapat direkomendasi sebagai bentuk pelaksanaan pengabdian masyarakat yang tepat.

Selain itu, Mulyawan (2012) menyatakan bahwa pelatihan merupakan kegiatan yang tepat dalam pengembangan profesional bagi guru. Pelatihan berbagai tema yang diselenggarakan oleh dinas, instansi, atau perorangan akan menjadi wadah untuk menggali informasi baru, menjaga, serta meningkatkan kompetensi guru.

Berdasarkan konsep tersebut, target luaran yang akan dicapai dalam kegiatan ini adalah karya tulis berupa gagasan guru yang bisa menjadi bahan bacaan siswa baik sebagai materi ajar atau pun pengayaan informasi. Target luaran tersebut akan diberikan oleh peserta untuk menunjukkan keberhasilan programyang dikerjakan. Adapun tahapan tahapan adalah Presentasi penyampaian program, Kerja individu dan kerja kelompok, Praktik pendampingan dan atau unjuk kerja, dan Refleksi dan atau evalusasi

Rincian tahapan kegiatan pada tahun 2019 ini dipaparkan pada rincian berikut.

a) Tahap penyampaian program

Pada tahap ini, para staf edukatif UPBJJ Universitas Terbuka Jember menyampaikan materi pentingnnya literasi untuk guru, mulai dari kegiatan membaca dan menulis. Membaca dan menulis di era digital berbeda dengan kegiatan membaca dan menulis di era sebelumnya. Perluadanya pemahaman dalam penggunaan literasi berbasis digital untuk guru PAUD dan SD.
Guru yang memiliki kompetensi literasi berbasis teknologi akan mampu menjadi bagian dari masyarakat yang mandiri dan berwirausaha.

Penyampaian program dilakukan sebanyak dua kali, satu kali telah dilakukan tanggal 25 Oktober 2019. Pada pertemuan ini disampaikan kegiatan membaca dan menulis yang bisa dilakukan guru. Dari kegiatan tersebut, guru dapat menciptakan kreasi untuk meningkatkan mutu pendidikan. Tidak hanya mutu pendidikan, tetapi guru juga bisa lebih mandiri dalam mengembangkan kegiatan sekolah yang menyenangkan. Disepakati dalam kegiatan perdana ini, guru akan berlatih menulis Lembar Kegiatan Anak dan Bahan Bacaan Anak yang akan menjadi buku yang ditulis Bersama oleh kelompok kerja guru PAUD dan SD.

Pada pertemuan kedua, akan disampaikan program publikasi ilmiah oleh guru. Publikasi ilmiah ini diakui belum banyak dipahami olehb guru baik PAUD aatau SD. Oleh sebab itu akan disampaikan urgensi literasi ilmiah untuk guru sehingga meningkatkan kualitas diri dan eksistensi profesionalisme mereka.

b) Tahap kerja individu dan kerja kelompok

Pada tahap ini, peserta akan menyusun tugas sesuai dengan materi yang disampaikan pada tahap sebelumnya. Peserta akan bekerja secara mandiri yang kemudian disusun secara bersama-sama dalam kerja kelompok.

c) Tahap pendampingan dan unjuk kerja 
Pada tahap ini, para peserta menunjukkan hasil kinerjanya pada program literasi guru. Hasil kinerja akan diberikan arahan dalam penyelesaian target yang akan dicapai.

d) Tahap refleksi dan evaluasi

Pada tahap ini, para staf edukatif UPBJJUniversitas TerbukaJemberdan juga peserta mengevaluasi kegiatan untuk mengukur keberhasilan program ini. Para peserta dari program ini bisa mendapatkan manfaat dari kegiatan literasi yang telah dilaksanakan.

\section{HASIL DAN PEMBAHASAN}

Hasil kegiatan ini akan dijelaskan sesuai tahapan yang dilaksanakan dalam kegiatan Abdimas tahun 2019.

1) Tahap penyampaian program

Pada tahap penyampaian program, ada dua tema bawahan dalam kegiatan literasi guru ini, yaitu konsep literasi guru secara umum dan konsep literasi ilmiah. Pada setiap kegiatan disampaikan motivasi untuk meningkatkan kompetensi literasi guru. Hal ini perlu disampaikan karena melalui guru yang sadar pentingnya literasi akan lahir generasi penerus yang juga mencintai literasi.

Dipaparkan dipertemuan pertama yaitu pentingnya literasi masa kini di era digital dan peluang menjadi bagian dari masyarakat yang mandiri dan berwirausaha melalui kegiatan literasi. Berdasarkan paparan tersebut beberapa guru memiliki inisiatif dan kesepakatan untuk menulis bersama yang diwujudkan dalam sebuah buku yang ditulis oleh guru-guru SD dan guru-guru PAUD di bawah gugus kegiatan guru.

Pada kegiatan tersebut,
didiskusikan luaran yang bisa menjadi bagian dari perjalanan usaha meningkatkan kompetensi literasi guru. Disepakati para peserta akan menyusun bahan bacaan untuk meningkatkan kompetensi guru dan memberikan layanan pendidikan yang sesuai dengan kebutuhan siswa. Pada kegiatan ini, disampaikan setiap peserta membuat karya sesuai dengan kompetensi mereka. Hasil kinerja akan ditunjukkan di akhir kegiatan Abdimas ini.

Kegiatan pelatihan pertama ini mendapatkan respon yang sangat positif, sehingga kami pun memiliki komitmen untuk memberikan layanan untukmerealisasikanmimpimenyusun dan menerbitkan buku bersama.

Pada pertemuan kedua, dipaparkan literasi ilmiah masakini. Ini perludisampaikanuntukmeningkatkan pengetahuan dan keterampilan guru dalam memperoleh, mengolah, dan memublikasi karya ilmiah yang telah dihasilkannya. Pengalaman menulis ilmiah di pendidikan strata satu sebelumnya akan menjadi bekal dalam pengembangan kemampuan menulis ilmiah ini. Berdasarkan kegiatan ini, beberapa guru ingin memublikasikan artikel ilmiah mereka di jurnal secara online. Namun, karena ketidaksiapan naskah, dibutuhkan waktu menunggu sampai artikel mereka bisa dikirim.

Pada kegiatan ini, disampaikan pula materi tentang urgensi peningkatan kompetensi guru melalui artikel ilmiah. Untuk mendukung kompetensi tersebut, disampaikan 
cara memaksimalkan penggunaan Microsoft word dalam menyusun karya ilmiah. Dikenalkan fungsi setiap menu dalam Microsoft word mulai dari aneka menu di home, insert, design, layout, references, mailings, review, dan view. Berikut salah satu tampilan materi pelatihan.

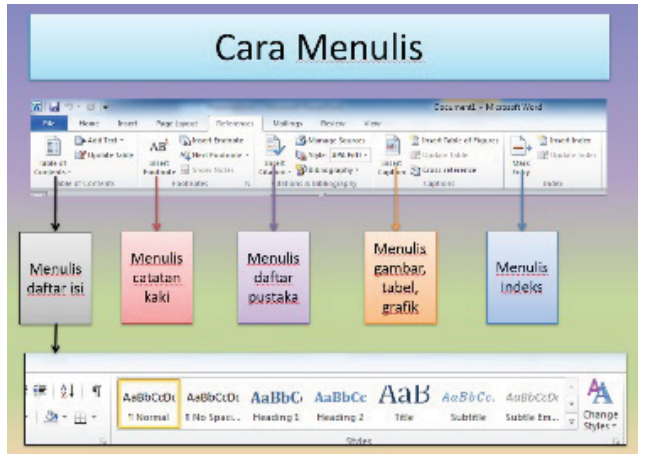

Gambar 1 Materi Pelatihan

Setiap menu tersebut memiliki fungsi dalam menulis karya ilmiah. Pada pelatihan tersebut disampaikan cara menulis dengan heading untuk bisa menyusun daftar isi dengan otomatis, cara menulis daftar pustaka, tabel, gambar, dan grafis melalui references.

Untuk mendapatkan pengalaman belajar yang menyenangkan, pada pelatihan ini, peserta juga memiliki kesempatan untuk bertanya dan berpraktik langsung dalam menulis dengan mengoptimalkan fungsi menu di Microsoft word. Namun, sebelum peserta melakukan praktik, dijelaskan cara langsung pada draf artikel ilmiah dari pemateri. Melalui draf tersebut, dipraktikkan cara penggunaan beberapa menu dalam Microsoft yang dipelajari. Berdasarkan simulasi tersebut, peserta memiliki kesempatan untuk bertanya dan berpraktik langsung dalam menulis dengan mengoptimalkan fungsi menu di Microsoft word.

Semua materi kegiatan telah dijelaskan dalam modul kegiatan yang dibagikan. Dengan harapan para peserta mampu meningkatkan kompetensi literasi dengan baik. Kompetensi literasi yang meningkat akan menjadi indikator peningkatan kompetensi guru profesional.

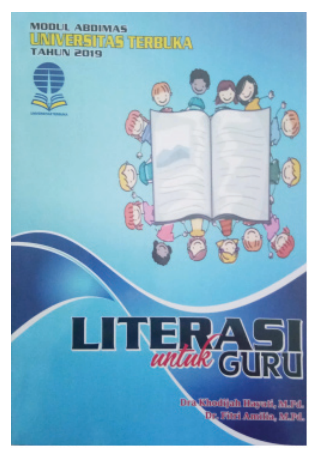

Gambar 2 Modul Kegiatan Abdimas tahun 2019

Dengan adanya modul tersebut, diharapkan peserta dapat membaca dan memahami kembali materi yang telah disampaikan. Hal ini sesuai dengan manfaat modul yang disampaikan Sungkono (2009), modul memiliki manfaat bagi guru dan murid. Dalam konteks kegiatan ini, guru adalah pelaksana Abdimas dan murid adalah peserta Abdimas. Manfaat bagi guru, modul sebagai bukti bahwa guru adalah fasilitator. Manfaat bagi murid yaitu mereka dapat terus belajar tanpa kehadiran guru. Hal ini juga sesuai dengan dugaan bahwa keterampilan menulis merupakan keterampilan yang harus terus diasah.

2) Tahap kerja individu dan kerja kelompok

Kerja individu dan kelompok dilakukan oleh setiap peserta. Hasil kerja peserta akan ditunjukkan saat pendampingan dan evaluasi. Berikut 
karya yang dihasilkan sebagai luaran kegiatan pelatihan pertama.
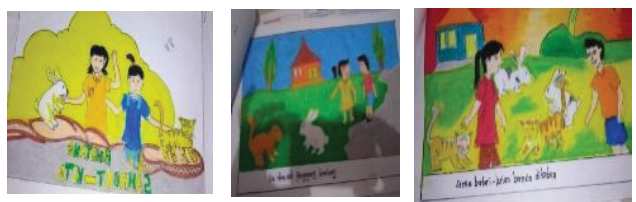

Gambar 3 Produk Peserta Berupa

Buku Cerita Bergambar

Gambar 3 tersebut menunjukkan peserta mengerjakan tagihan individu untuk membuat bahan bacaan untuk siswa. Gurumembuat cerita bergambar dengan tema sahabat. Luaran ini dikerjakan untuk bisa menghasilkan buku yang ditulis oleh semua peserta pelatihan.

Peserta lainnya menyusun Lembar Kerja Siswa dengan tema Binatang, subtema makanan binatang. Berikut karyanya.

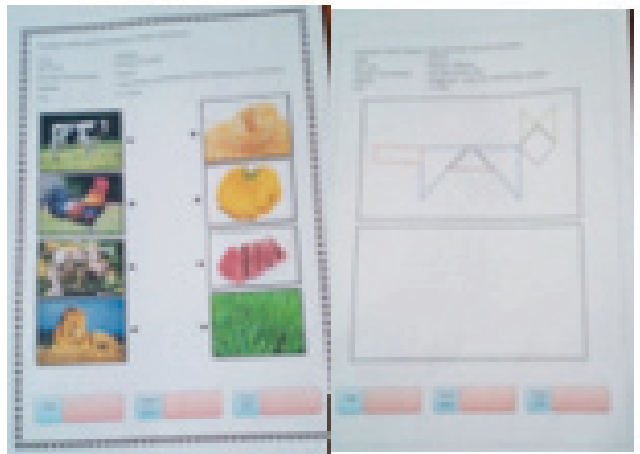

Gambar 4 Produk Peserta Lembar Kerja Siswa

Variasi produk yang dihasilkan para peserta pelatihan memiliki kesulitan dalam pemaduan buku yang akan direncanakan diterbitkan. Untuk itu, diperlukan komitmen kuat dari semua peserta untuk menghasilkan buku yang diterbitkan sesuai dengan komitmen awal dalam kegiatan pelatihan.

Pada kegiatan Abdimas ini, produk berupa artikel ilmiah belum dipublikasikan. Ada banyak faktor atas kondisi ini, faktor utamanya adalah kompetensi dan habituasi menulis ilmiah. Untuk menghasilkan luaran berupa artikel ilmiah, dibutuhkan pendampingan yang serius. Pendampingan itu dilakukan sejak kegiatan menulis ide hingga publikasi. Jika pendampingan tidak dilakukan hingga tuntas, kelayakan artikel belum bisa dicek secara valid melalui publikasi di jurnal ilmiah nasional. Dengan demikian, dapat disimpulkan menulis artikel ilmiah memerlukan usaha yang lebih konsisten dari peserta kegiatan Abdimas.

3) Tahap pendampingan dan unjuk kerja

Pendampingan dilakukan untuk memberikan layanan kepada peserta untuk mendapatkan pengalaman belajar yang baik. Pengalaman belajar yang menyenangkan akan menjadi bekal dalam pengembangan literasi di masa yang akan datang. Buku karya guru dicetak oleh tim pelaksana Abdimas. Produk ini menjadi bukti konkret kinerja dan performa mereka dalam kegiatan menulis.

4) Tahap refleksi dan evaluasi

Refleksi dan evaluasi akan dilakukan kemudian setelah rangkaian kegiatan Abdimas Literasi Guru telah tuntas. Refleksi untuk pelatihan pertama sudah dilakukan tanggal 20 bulan November 2019. Refleksi kegiatan kedua dilakukan 29 November 2019. Evaluasi kegiatan akan dilakukan setelah karya peserta dikumpulkan di bulan 15 Desember 2019.

Hasil dari kegiatan refleksi dan 
evaluasi, disimpulkan bahwa pelatihan ini bermanfaat untuk peningkatan kompetensi guru. Rangkaian kegiatan dalam pelatihan ini memberikan pengalaman belajar yang menyenangkan. Semua guru memiliki bakat dan potensi tersembunyi, melalui pelatihan ini, guru bisa mengekspos kemampuannya dalam menulis.

\section{SIMPULAN}

Kemampuan menulis merupakan kemampuan dimiliki seseorang dengan proses belajar yang lebih panjang. Komitmen yang kuat untuk terus menerus belajar menulis akan menjadi dasar dalam pengembangan potensi diri dalam menulis. Untuk itu, setiap guru harus memiliki komitmen pengembangan diri yang baik. Melalui kegiatan Abdimas ini, semua guru diharapkan terus meningkatkan komitmen dalam pengembangan diri, khususnya menulis. Dengan menulis, kompetensi guru akan meningkat; murid mendapatkan teladan untuk pengembangan diri yang lebih baik.

Melalui kegiatan Abdimas ini, pengembangan kegiatan literasi menjadi media belajar guru untuk menjadi pribadi yang mandiri dan berwirausaha di bidang pendidikan melalui kemampuan literasi yang baik. Penyiapan sumberdaya manusia yang literat diperlukan komitmen dan kerja sama semua pihak, sehingga guru mampu memberikan contoh untuk melahirkan generasi yang literat.

\section{UCAPAN TERIMA KASIH}

Disampaikan terima kasih kepada Lembaga Penelitian dan Pengabdian Masyarakat Universitas
Terbuka yang telah membiayai rangkaian kegiatan Abdimas dalam tiga tahun kegiatan. Kegiatan ini merupakan rangkaian kegiatan Abdimas di Desa Pakusari dengan tema literasi sejak tahun 2017 lalu. Kegiatan tahun pertama bertema literasi administrasi untuk staf desa. Kegiatan tahun kedua bertema literasi teknologi untuk pegiat usaha. Terakhir, tahun 2019, kegiatan Abdimas bertema literasi untuk pegiat pendidikan.

\section{DAFTAR PUSTAKA}

Amilia, F. (2018). Pemahaman dan habituasi untuk membangun kompetensi menulis praktis dan ilmiah. Lingua Franca: Jurnal Bahasa, Sastra, dan Pengajarannya, 22-31.

Amilia, F. (2018). Peran guru dalam pengembangan literasi sekolah. Seminar Nasional dan Workshop Metodologi Penelitian Pendidikan (pp. 15-22). Palangkaraya: Mitra Mandiri Persada.

Direktorat Jenderal Pendidikan Dasar. (2015). Buku saku gerakan literasi sekolah: menumbuhkan budaya literasi di sekolah. Jakarta: Kementerian Pendidikan dan Kebudayaan.

Fitria, H., Kristiawan, M., \& Rahmat, N. (2019). Upaya meningkatkan kompetensi guru melalui pelatihan penelitian tindakan kelas. Abdimas Unwahas, 4(1), 14-25.

Mulyawan, B. (2012). Pengaruh pengalaman dalam pelatihan terhadap peningkatan kompetensi profesional guru. Media Komunikasi FPIPS, 11(1), 45-65.

Musfah, J. (2012). Peningkatan kompetensi guru: melalui pelatihan dan sumber belajar 
teori dan praktik. Jakarta:

Kencana.

Richards, J. C., \& Farrell, T. S. (2005). Professional development for language teachers: Strategies forteacherlearning. Cambridge: Cambridge University Press.

Sa'bani, F. (2017). Peningkatan kompetensi guru dalam menyusun RPP melalui kegiatan pelatihan pada MTs Muhammadiyah Wonosari. Jurnal Pendidikan Madrasah, 2(1), 13-22.

Sodiq, I., Suryadi, A., \& Ahmad, T. A. (2014). Program guru menulis: upaya peningkatan komepetensi profesional guru sejarah dalam penulisan karya ilmiah di Kabupaten Semarang. Rekayasa: Jurnal Penerapan Teknologi dan Pembelajaran, 12(1), 42-47.

Sungkono.(2009). Pengembangan dan pemanfaatan bahan ajar modul dalam proses pembelajaran. Majalah Ilmiah Pembelajaran, 5(1), 1-13. 